\title{
PENGUATAN KEMAMPUAN SOSIAL PADA PENATAAN KAWASAN KUMUH PERKOTAAN (Studi Kasus Kelurahan Cigugur Tengah Cimahi)
}

\author{
Social Enrichment In Slum Urban Areas Rearrangement Program
}

\author{
Yudha P. Heston ${ }^{1}$ dan Ahmad Yusuf $A^{1}$
}

Diterima : 11 Februari 2013 Disetujui : 26 April 2013

\begin{abstract}
Abstraksi : Fokus penelitian ini adalah untuk mengukur dan mengidentifikasi faktor-faktor yang dapat menguatkan kemampuan sosial, baik bagi pemerintah maupun masyarakat pada penataan kawasan kumuh perkotaan dengan mengambil studi kasus di kelurahan Cigugur Tengah kota Cimahi. Metode penelitian yang dilakukan adalah Participatory Research Appraisal (PRA) untuk memastikan keterlibatan aktif dari masyarakat yang menjadi kelompok sarasan. Berdasarkan hasil penelitian, peneliti memiliki kesimpulan bahwa keberhasilan penguatan sosial pada penataan daerah kumuh perkotaan sangat bergantung pada peningkatan kapasitas governansi pemerintah dan komunitas masyarakat. Peningkatan kapasitas governansi pemerintah dapat dilakukan dengan mendorong Pimpinan Daerah, memberikan komitmen untuk menetapkan Kawasan Prioritas dalam peningkatan kualitas sosial wilayah. Membentuk unit kerja Pengelola Kawasan yang memiliki tugas meningkatkan kualitas sosial pada penataan kawasan kumuh. Peningkatan kapasitas governansi komunitas masyarakat dapat dilakukan dengan pemberian komitmen warga, terlibat aktif dalam pengambilan keputusan, perencanaan, implementasi, pemeliharaan, pengawasan dan kontribusi peningkatan kualitas sosial ekonomi pada penataan kawasan kumuh prioritas.
\end{abstract}

Kata kunci : penguatan, sosial, penataan, kawasan, kumuh.

ABSTRACT: The focus of this research is to measure and identify the factors that can enrichment social skills, both for the government and society in rearrangement urban slum with a case study in Kelurahan Cigugur Tengah Cimahi city. Research methodology is Participatory Research Appraisal (PRA), to ensure the active involvement of the people who became the subject group. Based on the results of the study, the researchers have concluded that the success of social assistance in rearrangement urban slums depend on increasing the capacity of governments and communities governansi. Increased capacity of government governance can be done by encouraging the Regional Executive, gave a commitment to establish priority areas for quality improvement of social areas. Forming a business unit area that has the task of improving the quality of social structuring slum. Increase the capacity of communities governance be done with the commitment of citizens, actively involved in decision-making, planning, implementation, maintenance, monitoring and improving the quality of social contribution in structuring slum priority.

Key words:enrichment, social, rearrangement, areas, slum.

\footnotetext{
${ }^{1}$ Peneliti Balai Litbang Sosial Ekonomi dan Lingkungan Bidang Permukiman

Jl. Adisucipto No 165 Yogyakarta 55281
} 


\section{Pendahuluan}

Kota sebagai tempat konsentrasi penduduk yang berpenghidupan non agraris (Sinulingga; 1999 dalam Hermanto, 2011), memiliki tugas untuk dapat melayani, memperhatikan, menguntungkan semua lapisan warga yang ada di dalamnya. Strategi pembangunan yang berpusat pada rakyat memiliki tujuan (Harry, 2000) untuk memperbaiki kualitas hidup rakyat berkaitan dengan aspirasi individu dan kolektif, dalam tradisi budayaperilaku kebiasaan yang berlaku. Sehingga kota perlu mengembangkan program yang tanggap kebutuhan sosial, termasuk dalam hal melakukan penataan kawasan kumuh.

Penataan kawasan kumuh di kawasan perkotaan memiliki beberapa kendala, salah satunya adalah terkait pemahaman standar permukiman yang layak. Selain itu faktor fungsional permukiman juga terkait dengan dimensi sosial, ekonomi, budaya, teknologi, ekologi bahkan politik (Suprijanto, 2004). Permasalahan terkait aspek sosial yang berhasil diidentifikasi Balai Litbang Sosial Ekonomi Bidang Permukiman (Tim Peneliti, 2010) adalah terkait dengan: belum optimalnya peran, kapasitas institusi dan pengelolaan dari pemerintah (kota) serta masyarakat terkait program penataan kawasan kumuh. Komunikasi pemerintah (kota) - masyarakat belum terlembaga dengan baik struktur dan fungsinya. Belum jelasnya konsep dan strategi implementasi program dari masing-masing dinas dan swasta terkait penataan kawasan kumuh.

Kondisi ideal yang diharapkan dari sebuah upaya peningkatan kemampuan sosial pada wilayaha kumuh perkotaan adalah ditemukannya kesiapan untuk berubah, adanya lahan yang dapat ditata dan meningkatnya peran dari masyarakat.

\section{Tujuan penelitian}

Penelitian dilakukan untuk mengukur dan mengidentifikasi faktor-faktor yang dapat menguatkan kemampuan sosial, baik bagi pemerintah maupun masyarakat pada penataan kawasan kumuh perkotaan dengan mengambil studi kasus di kelurahan Cigugur Tengah kota Cimahi.

\section{Metodologi}

Penelitian dilakukan dengan pendekatan kualitatif dengan metode Participatory Research Appraisal (PRA). Metode penelitian ini digunakan untuk memastikan keterlibatan aktif dari masyarakat yang menjadi kelompok sarasan. Penelitian PRA (Handayani, 2009) menempatkan masyarakat yang menjadi kelompok sasaran sebagai 'subjek' dalam proses kegiatan, dan bukan sebagai 'objek'. Dalam PRA, peneliti adalah pihak yang terlibat aktif di dalam program kegiatan. Pelaksanaan kegiatan penelitian dilakukan dengan menyusun rencana, instrumen/indikator, melakukan pengumpulan data, pengolahan, analisis dan menyusun laporan bersama kelompok sasaran.

Penelitian di lakukan di Kelurahan Cigugur Tengah Kota Cimahi yang merupakan kawasan strategis di lingkungan industri dan pedagangan di Kota Cimahi. Terdapat juga kawasan perdagangan di Jalan Leuwigajah dan Jalan Cimindi yang membatasi wilayah Cigugur Tengah. Luas wilayah Cigugur Tengah adalah 235 hektar, yang penuh dengan bangunan, dengan jarak antar bangunan sebagian besar sempit. Subyek penelitian adalah masyarakat di RW 05, meliputi seluruh RT (1-9) yang ada di dalam RW tersebut.

\section{Gambaran Lokasi Penelitian}

Jumlah penduduk Kota Cimahi, tahun 2010 607,514 jiwa. 18\% atau kurang lebih 80 ribu jiwa adalah penduduk Pra Keluarga Sejahtera (pra KS). Tingkat pertumbuhan rata-rata penduduk Kota Cimahi adalah \%/tahun. Kepadatan penduduk rata-rata tahun 2011 adalah 151 jiwa/ha. Wilayah kelurahan Cigugur Tengah (235 jiwa/ha) di Kota Cimahi merupakan 
wilayah terpadat ketiga setelah Cibereum (267 jiwa/ha) dan Melong 240 (jiwa/ha). Gambaran kondisi sosial penduduk di RW 05 dan kepadatannya dapat diperhatikan pada gambar 1 dan 2. Penggunaan lahan di RW. 05 didominasi permukiman, dengan luas 4.6623 ha, status kepemilikan tanah dapat diperhatikan pada gambar 3.

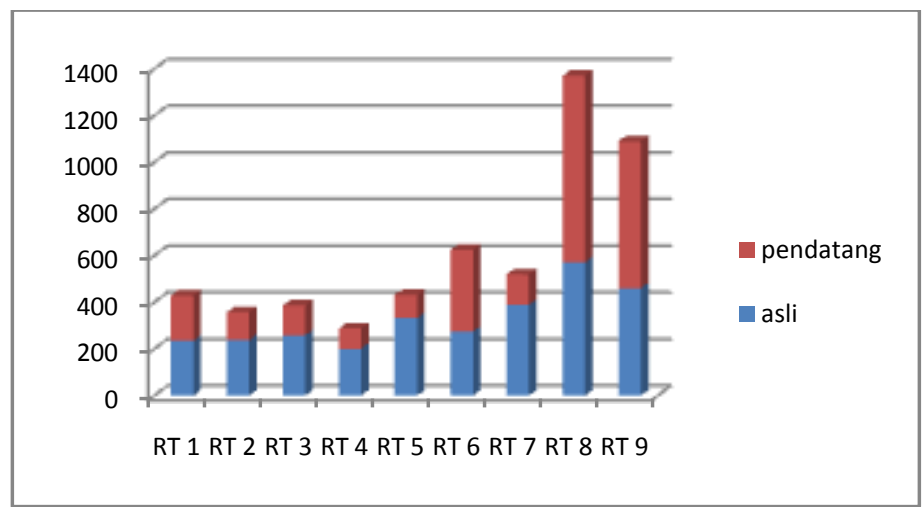

Gambar 1. Jumlah Penduduk dan Asalnya di Kawasan RW.05 Kelurahan Cigugur Tengah

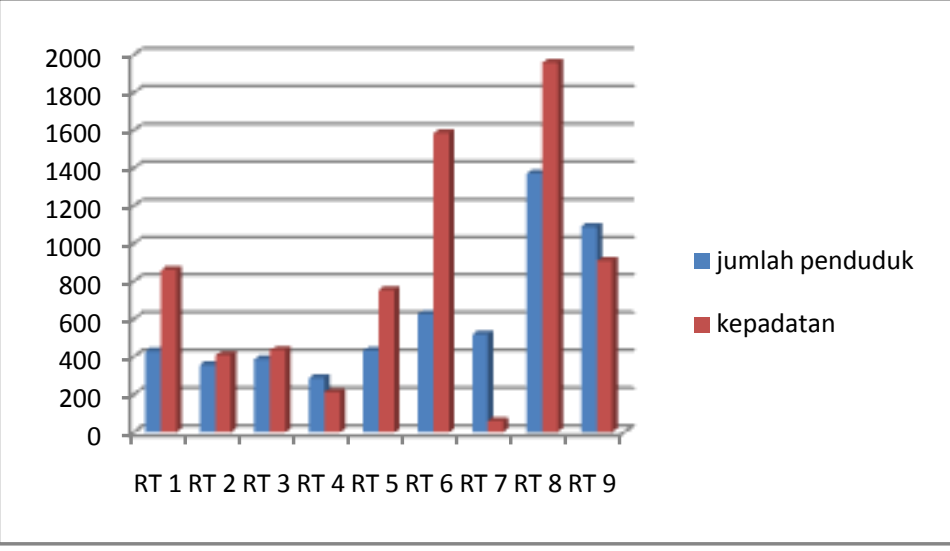

Gambar 2. Kepadatan Penduduk RW. 05 Kel. Cigugur Tengah

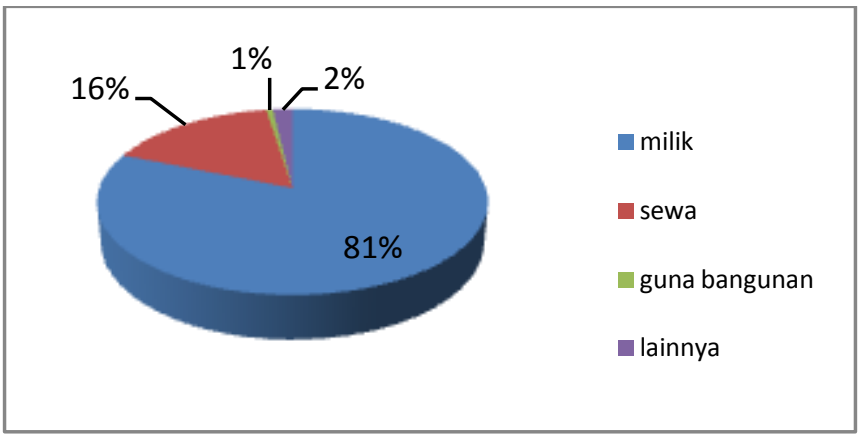

Gambar 3. Kepadatan Penduduk RW. 05 Kel. Cigugur Tengah 


\section{Kajian Pustaka}

Peningkatan rata-rata penduduk perkotaan pertahun (Andini, 2013) adalah sebesar 3,45\% berdasarkan laporan Divisi Kependudukan Dewan Ekonomi dan Sosial PBB (2006). Pada tahun 2001, UN-Habitat menghitung perkiraan proporsi penduduk Indonesia yang tinggal di daerah padat kumuh, yaitu sebesar 23\%, (sekitar 21 juta jiwa) dari seluruh penduduk yang tinggal di wilayah perkotaan.

Daerah kumuh adalah daerah di mana rumah dan kondisi hunian masyarakat di daerah tersebut sangat buruk. Rumah maupun sarana dan prasarana yang tidak sesuai dengan standar yang berlaku, baik standar kebutuhan, kepadatan bangunan, persyaratan rumah sehat, kebutuhan sarana air bersih, sanitasi maupun persyaratan kelengkapan prasarana jalan, ruang terbuka, serta kelengkapan fasilitas sosial lainnya (Kurniasih Sri, 2007 dalam Andini, 2013).

Penyediaan perumahan dan permukiman, harus dapat menjawab beberapa kebutuhan sesuai dengan standar kelayakan tinggal (Depkes RI, 2005 dalam www.Indonesia-publichealth.com), yaitu dapat memenuhi kebutuhan fisiologis (pencahayaan, penghawaan, ruang gerak yang cukup dan terhindar dari gangguan kebisingan), kebutuhan psikologis (privacy yang cukup, komunikasi yang sehat antara anggota keluarga), memenuhi persyaratan pencegahan penularan penyakit (penyediaan air bersih, pengelolaan tinja dan limbah rumah tangga, bebas vektor penyakit, terlindungnya makanan dan minuman dari pencemaran) dan memenuhi persyaratan pencegahan terjadinya kecelakaan, (garis sepadan jalan, konstruksi yang kuat, tidak mudah terbakar, dan tidak cenderung menimbulkan kecelakaan bagi penghuninya). Penyediaan permukiman dilakukan dengan melaksanakan program pembangunan.

Pembangunan berkelanjutan terkait penataan wilayah, menurut Utomo, 2003 (dalam Widigdo) mempunyai tiga dimensi, yaitu: Ekonomi, terkait ekonomi lokal, lapangan kerja, peningkatan pendapatan rakyat, pasar yang adil dan fair. Sosial, politis dan budaya, terkait konsep berbasis komunitas, yaitu pembangunan adil sosial, demokratis terbuka, otonomi daerah dan lokal, peka keragaman budaya, peran serta dan pemberdayaan penduduk lokal. Lingkungan, terkait perencanaan lingkungan, yaitu hemat sumber daya, teknologi tepat guna dan mengurangi limbah, memperhitungkan daya dukung lingkungan, konservasi dan preservasi alam.

Tumbuhnya pusat-pusat perdagangan dan permukiman (Basri dkk, 2010) mendorong masyarakat dalam mengoptimalkan pemanfaatan lahan, mengakibatkan tekanan terhadap daya dukung lingkungan, sehingga lingkungan cenderung menjadi kumuh. Penanganan yang dapat dilakukan adalah dengan mensinkronkan kebijaksanaan Pemerintah Kota untuk meningkatkan kualitas lingkungan dan kehidupan masyarakat. Masyarakat disini dapat didefinisikan sebagai konsumen akhir dari pasar perumahan.

Menurut Tjuk Kuswartojo (Tanuwidjaja, 2009), seharusnya tahapan yang harus ditempuh dalam pembangunan perumahan itu didasarkan kepada analisa terhadap kebutuhan perumahan dan demografi yang ada. Kemudian dituangkan dalam kebijakan perumahan dan instrumen penerapannya agar sesuai sasaran. Sehingga, dengan kata lain harus muncul pemberdayaan masyarakat dalam penyediaan perumahan dan permukiman.

Tujuan pemberdayaan adalah untuk memperkuat kemampuan khususnya bagi kelompok lemah yang memiliki ketidakberdayaan, baik karena kondisi internal, maupun kondisi eksternal (Edi Suharto, 2005 dalam Andini, 2013). Secara konseptual, pemberdayaan masyarakat adalah upaya untuk meningkatkan harkat dan martabat lapisan masyarakat yang dalam kondisi sekarang tidak mampu untuk melepaskan diri dari perangkap kemiskinan dan keterbelakangan. Dengan kata lain memberdayakan adalah memampukan dan memandirikan masyarakat. 


\section{Analisis}

Analisis yang dilakukan dengan mencari nilai-nilai penting terkait fenomena sosial, dalam pelaksanaan kegiatan dibagi menjadi tiga fase yaitu: fase persiapan partisipasi masyarakat, fase perancangan program dan fase partisipasi masyarakat. Masing -masing fase dapat dijelaskan sebagai berikut.

\section{Fase Persiapan Partisipasi Masyarakat}

Pada fase persiapan, dilakukan perencanaan untuk melibatkan warga dalam pengumpulan data dan identifikasi masalah setelah berkoordinasi dengan Pemerintah Kota Cimahi serta melakukan kunjungan lapangan. Kegiatan ini mendapatkan temuan terkait kondisi psikologis warga yang trauma terhadap program konsolidasi lahan dan rumah susun, perlu adanya keterlibatan tokoh warga untuk menjamin keberhasilan program, adanya perbedaan definisi kumuh antara pemerintah kota dengan warga. Langkah ini dilanjutkan dengan merencanakan adanya kegiatan "pemetaan swadaya". Pemetaan swadaya dikenal di Direktorat Jenderal Cipta Karya sebagai Survey Kampung Sendiri.

Sosialisasi pemetaan swadaya, dilakukan serial mulai dari tingkat kelurahan (Cigugur Tengah), tingkat RW (05), tingkat RT (1-9) termasuk tokoh masyarakat. Sosialisasi dibantu tenaga fasilitator yang mengenal budaya dan perilaku setempat.

Pemetaan swadaya dilakukan dengan membentuk Tim Pendamping Masyarakat (TPM) yang dilakukan warga masyarakat dalam forum rembug warga. Metode ini digunakan untuk memastikan kepercayaan warga akan program dan pelaksananya. Hasilnya adalah bahwa TPM beranggotakan para Ketua RT di RW 05 Cigugur Tengah. TPM bertugas menggali informasi, potensi dan permasalahan di lingkungan. TPM kemudian dibekali materi teknis pelaksanaan pemetaan swadaya oleh Tim Peneliti.

Proses pengumpulan data dilakukan dengan penyebaran kuesioner, wawancara dan diskusi, dan memetakan kondisi lingkungan serta permasalahan yang dihadapi. Data yang dikumpulkan terkait identifikasi jumlah Kepala Keluarga, kondisi prasarana dan sarana permukiman, kondisi sumber daya manusia, potensi ekonomi dan sumber daya alam.

Data yang terkumpul kemudian diolah dalam diskusi kelompok terarah (focus group discussion/FGD). Dalam FGD pertama ditemukan hasil terkait kondisi rumah yang kurang memenuhi standar kesehatan, keselamatan, dan kenyamanan. FGD kedua memiliki agenda penentuan prioritas tindak lanjut penanganan masalah yang dituangkan dalam Rancangan Program RW 5. Beberapa kebutuhan yang terungkap terkait: penanganan limbah cair rumah tangga dan limbah padat, rencana program penanganan sampah, perbaikan saluran drainase, penambahan sumber air bersih, perbaikan jalan lingkungan, penghijauan, dan penataan permukiman/bangunan. FGD ketiga dilakukan dengan melibatkan beberapa instansi pemerintah yang diperkirakan memiliki jawaban permasalahan yang sudah dirumuskan pada FGD kedua.

\section{Fase Perancangan Program}

Perancangan program dilakukan dengan menginisiasi pembentukan Kelompok Kerja Operasional (Pokjanal) yang beranggotakan pegawai dari instansi terkait pada Pemerintah Kota Cimahi untuk melaksanakan program di Cigugur Tengah. Pembentukan Pokjanal dilanjutkan dengan rembug warga di setiap wilayah RT. Dalam rembug warga disampaikan rencana pemberian stimulan yang harus dikelola oleh kelompok usaha. Rembug warga berikutnya dilakukan untuk membentuk Kelompok Usaha Warga Ciputri Cimahi (KUWACI) pada 9 RT.

Setelah Pokjanal dan KUWACI terbentuk, Tim Peneliti melaksanakan FGD (KUWACI) untuk memperkenalkan penyusunan proposal dan pengelolaan keuangan kelompok. Dalam FGD juga ditentukan prioritas program yaitu perbaikan drainase dan 
jalan lingkungan. Sebagai pendukung program, disiapkan peta swadaya drainase dan jalan lingkungan dengan bimbingan dari Pokjanal. FGD (Pokjanal) kemudian dilakukan untuk mendiskusikan Rancangan Program Pokjanal 2010 yang akan dilaksanakan di wilayah Cigugur Tengah. Hal ini perlu dilakukan supaya terjadi keterpaduan program antara setiap instansi. FGD berikutnya dilakukan dengan tujuan untuk mensinkronisasi kebutuhan KUWACI dengan program Pokjanal. Dalam FGD ini ditemukan cara kompetisi untuk penerapan insentif kelompok.

\section{Fase Implementasi}

Pada tahun 2010 kegiatan memasuki fase implementasi program. Program kegiatan yang dilaksanakan terkait dengan perbaikan saluran drainase dan jalan lingkungan. Aspek fisik program dilakukan bersamaan dengan meningkatkan kapasitas kelembagaan masyarakat (KUWACI). Materi peningkatan kapasitas terkait: penyusunan program kelompok, simulasi penyusunan proposal, dan simulasi pengelolaan dana kelompok. Selain itu juga disiapkan dana stimulan Rp 3 juta per kelompok.

Kegiatan dengan melibatkan keterpaduan unsur pemerintah dan komunitas warga memunculkan hasil kesimpulan terkait dengan perlunya sinkronisasi dan integrasi program instansi Pemerintah (Pusat dan Daarah), evaluasi kinerja kelompok dan penentuan prioritas program di masyarakat.

\section{Model Penguatan Sosial}

Penguatan sosial dilakukan untuk dapat mencapai keterpaduan dan keberlanjutan peran dan kapasitas pemangku kepentingan yang terlibat dalam penataan kawasan kumuh perkotaan. Keterpaduan dan keberlanjutan dilakukan dengan mengintegrasikan program dan mensinergikan kinerja antar pemangku peran.

Peningkatan peran dan kapasitas masyarakat dilakukan melalui kegiatan disemua fase: Persiapan (pelaksanaan SKS, Analisis hasil SKS, dan penyusunan usulan prioritas program), Perancangan Program (Sinkronisasi program masyarakat dengan program Dinas/Badan di lingkungan Pemerintah Kota Cimahi, dan Implementasi program (mendukung dan melaksanakan program terpadu). Peran masyarakat dalam implementasi program, yaitu dengan partisipasi sebagian masyarakat merelakan tanahnya untuk pembangunan prasarana umum (drainase dan jalan lingkungan).

Peningkatan peran dan kapasitas Pemerintah Daerah dilakukan dengan: Pembentukan Kelompok Kerja Operasional (pokjanal), yang membuktikan komitmen Pemerintah Kota Cimahi untuk pengelolaan program penataan kawasan kumuh. Forum koordinasi antara Pokjanal dengan masyarakat yang dilaksanakan dalam Focus Group Discussion (FGD), dengan agenda membahas tentang penanganan permasalahan dan pengembanngan potensi kawasan. Program kerjasama antara Pemerintah Kota Cimahi yang terdiri dari institusi Dinas dan Badang dengan komunitas masyarakat, yang bertujuan untuk menata kawasan kumuh dapat diperhatikan pada gambar 4. Penguatan sosial masyarakat dalam penataan kawasan kumuh dapat ditempuh melalui pembentukan dan perkuatan kelembagaan yang ada di masyarakat. Dalam kasus kegiatan ini diwujudkan dalam pembentukan KUWACI disetiap RT. KUWACI dimaksudkan sebagai embrio bagi terwujudnya Kelompok Pengelola Kawasan tingkat RT.

Penguatan KUWACI dilakukan melalui pembekalan materi dan simulasi dalam FGD. Materi yang disampaikan terkait: Tata Cara Penyusunan Program, Simulasi Penyusunan Proposal dan Simulasi Pengelolaan Dana Kelompok. Disiapkan pula Dana Stimulan sebagai sarana praktek pembelajaran pengelolaan dana kelompok. Hal ini perlu untuk dilakukan, sebagai usaha mewujudkan kelompok masyarakat yang akungambar, transparan, dan dipercaya oleh lembaga keuangan, sehingga dapat mengakses sumber pembiayaan 
pemerintah atau swasta yang ada. Evaluasi dilakukan kepada pengelolaan dana stimuan pada KUWACI dengan hasil pada tabel 1 dan 2.

\begin{tabular}{|c|c|c|c|c|}
\hline \multicolumn{5}{|c|}{ 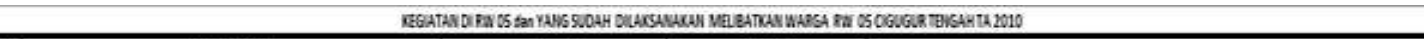 } \\
\hline 国 & KEEALINAN & instiensi & Javes & Keterangan \\
\hline 1 & Koontinas, seikroibasikonsep & Bappeda & rooses, dishos & Integas, koodsnas itę atan tim pokjanai dan nva \\
\hline 2 & Mornalissis galuras suggai Ciponi & DefK & Fisk B Pentedaban & 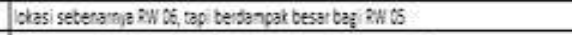 \\
\hline 3 & Sosialisasi Back Sampath & ofex & Fisik B pelathan & Uasih merari lokas unsuk tindak lanju: akibat ketetcarasan ahan \\
\hline 4 & Pengadaas Talebura & ofe & Felathan, Fenberdajaan & 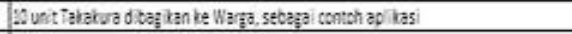 \\
\hline 5 & Bedah Ramah & ofe & Fisk & 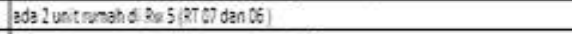 \\
\hline 6 & Pelocthan Keninusahaan & \multirow{6}{*}{ IPNPPS } & Fenbetapasn & Dharpian tuntuh js a kevirausahaan aba \& crang peseta \\
\hline 7 & Pelactitan Kaster Pospando & & Penbedapan & Lorerg kupe athan prograt \\
\hline 8 & sosiálias Peningkatas elononi Kelvarga UPPYS & & Somulen B Femberdagan & 2 ke ompok s app d sanping i in UPFIS \\
\hline 3 & Pelayanan Penasangan Kootrasepe' & & Fenbeda/aan & sudah dilaksanaken \\
\hline $\mathrm{E}$ & Kelenbagaan BBGR & & Fenbeda,asn & Uenbanty progam Besah Sunah bersinegig dergan DFU. \\
\hline$\pi$ & Pentinaze PoKtis [ Kelonpok Kezahanan Kelvarga) & & Pentertajaan & 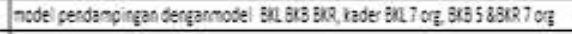 \\
\hline 2 & sosialisasi terang ksperas & Distopindeg̨ten & Pentedajaan & Leberianjutan KU:LE: \\
\hline 운. & sosialisas' Propram Beasising & \multirow{2}{*}{ DSSOK } & Stimulan & 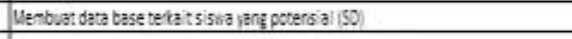 \\
\hline$x$ & PNDO & & Pentedbajan & sinegi dengun Poglardu dharapkan dapat terea i isirtahun depan \\
\hline 8 & Penbertukan nues & DSOUK & Stimulan B Fenberdajaan & 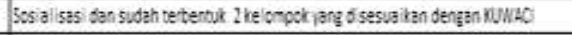 \\
\hline$\overline{8}$ & Peninglotan Prascrana Lingkegan & OPTAXAXYA & Fisik & sudah di zksaraken \\
\hline D & Koorfinagi & Psithangion & rosses & nasutan horsep dasar penatazn kzeasan \\
\hline 8 & Kourdnasi, FGD dan Pendanpingan KUKAO & Psifteng Sebranmas/Soseking & $\begin{array}{l}\text { Kocsep Penberdagan dan } \\
\text { Stimulan }\end{array}$ & 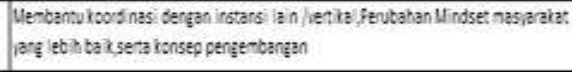 \\
\hline 8 & Operasiond Posando & DNAES & 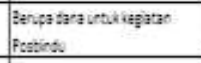 & 5.dah dil aksanakan \\
\hline 20 & FW S'aza & OMNES & Felatin, Ferbetayan & lebih hurang sa: kte onpok ata 20 orang pe $R$ W. \\
\hline in & 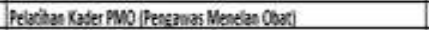 & DOSES & PelmanciaserfuO & Peseak anfes PW 1 orarg \\
\hline 2 & Banosin Fasilatas' Ganber unik WB & Em & Genudatanfogyz= & Disoof nas ian dergantin Pokjanal \\
\hline $2 s$ & Pentemuan PGQ6 dan C5R & 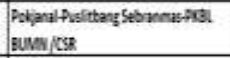 & Dows Fragar & 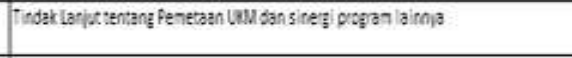 \\
\hline at & Kébutsertan dalam lonba Masajemen hovasi Peristaza, Depdagri & Pelianal & Fraserasidar foncsifrcgan & nenunga infornas cenenarg ionba \\
\hline
\end{tabular}

Gambar 4. Capaian Program Pemerintah (Sumber: Bappeda Kota Cimahi, 2010)

Tabel 1. Urutan dan keterangan KUWACI

\begin{tabular}{lll}
\hline Rangking & KUWACI & \multicolumn{1}{c}{ Keterangan } \\
\hline 1 & Kuwaci 01 & Informasi Riil \& Adm Sistematis \\
2 & Kuwaci 05 & Adm Sitematis, belum sepenuhnya terbuka \\
3 & Kuwaci 03 & Pemanfaatan pada kegiatan pinjaman social \\
4 & Kuwaci 06 & Perguliran lancar tetapi masih seputar keluarga pengurus \\
5 & Kuwaci 08 & Bergulir tetapi adm pinjaman belumm tertata \\
6 & Kuwaci 02 & Jujur, menerapkan sanksi tegas pada peminjam yang macet \\
7 & Kuwaci 09 & Bergulir tapi tidak focus pada bidang usaha bsar pinjaman yang digulirkan \\
& & sedikit rata2 100rb/kk \\
8 & Kuwaci 07 & Adanya pergantian RT manajemen belum rapi \\
9 & Kuwaci 04 & Tidak ada Data \\
\hline
\end{tabular}

Sumber: Tim Peneliti, 2010

Sinergitas kinerja dan integrasi program yang dilakukan, terbukti dapat meningkatkan efektivitas program kerja pemerintah daerah, terkait penataan kawasan dan mengembangkan kapasitas kemitraan pemerintah daerah dan masyarakat, dalam penanganan kawasan kumuh. Penguatan sosial diperlukan dengan tujuan akhir untuk menyiapkan masyarakat kearah perubahan dalam upaya meningkatkan kesejahteraan. Adanya partisipasi masyarakat berupa kontribusi lahan untuk investasi infrastruktur dan peningkatan peran masyarakat dalam proses penataan daerah kumuh. Dalam proses mencapai tujuan ini dapat muncul dinamika masyarakat mulai dari adanya penolakan, pencarian informasi sampai munculnya komitmen. 
Tabel 2. Tahapan dan capaian Kuwaci Oktober 2009 - Maret 2010

\begin{tabular}{rrrrrrrrr}
\hline Kuwaci & $\begin{array}{c}\text { Stimulan } \\
\text { awal } \\
\text { (yg } \\
\text { digulirkan) }\end{array}$ & $\begin{array}{c}\text { Anggota } \\
\text { peminjam } \\
\text { awal }\end{array}$ & $\begin{array}{c}\text { Anggota } \\
\text { perguliran }\end{array}$ & $\begin{array}{c}\text { Jumlah } \\
\text { s/d } \\
\text { maret }\end{array}$ & $\begin{array}{c}\text { aset yg } \\
\text { digulirkan }\end{array}$ & kas & $\begin{array}{c}\text { Rata-rata } \\
\text { pinjaman }\end{array}$ & Ranking \\
\hline 01 & $3,000,000$ & 10 & 5 & 15 & $3,060,000$ & 315,000 & 300,000 & 1 \\
02 & $3,000,000$ & 10 & 0 & 10 & $3,715,000$ & 36,000 & 300,000 & 6 \\
03 & $3,000,000$ & 10 & 2 & 12 & $3,399,000$ & $1,199,000$ & 300,000 & 3 \\
04 & $3,000,000$ & 10 & 0 & 10 & $3,000,000$ & - & 300,000 & 9 \\
05 & $3,000,000$ & 10 & 10 & 20 & $3,000,000$ & 240,000 & 300,000 & 2 \\
06 & $3,000,000$ & 10 & 3 & 13 & $3,000,000$ & 12,000 & 300,000 & 4 \\
07 & $3,000,000$ & 10 & 0 & 10 & $3,000,000$ & 120,000 & 300,000 & 7 \\
08 & $3,000,000$ & 10 & 5 & 15 & $3,000,000$ & 67,000 & 300,000 & 5 \\
09 & $2,500,000$ & 10 & 12 & 22 & $3,500,000$ & 500,000 & 200,000 & 8 \\
Jumlah & $26,500,000$ & 90 & 37 & 127 & $28,674,000$ & $2,489,000$ & & \\
\hline
\end{tabular}

Sumber: Tim Peneliti, 2010

Tiga aspek utama terkait penataan wilayah yaitu institusi, infrastruktur dan intervensi selektif dipandu oleh manajemen perubahan nyata dalam kasus penataan kawasan kumuh di Cigugur Tengah kota Cimahi. Variabel tersebut perlu ditambah dengan pengelolaan komunikasi, terkait dengan metode, waktu, agenda, tempat dan hal lain dalam komunikasi.

Input yang diperlukan untuk keberhasilan penguatan sosial pada penataan kawasan kumuh paling tidak terdiri dari empat hal, yaitu penggalian potensi masyarakat, sinkronisasi program pemerintah, pengembangan potensi kawasan, dan aplikasi kebijakan dan peraturan. Dinamika penguatan sosial dapat diperhatikan pada gambar 5.

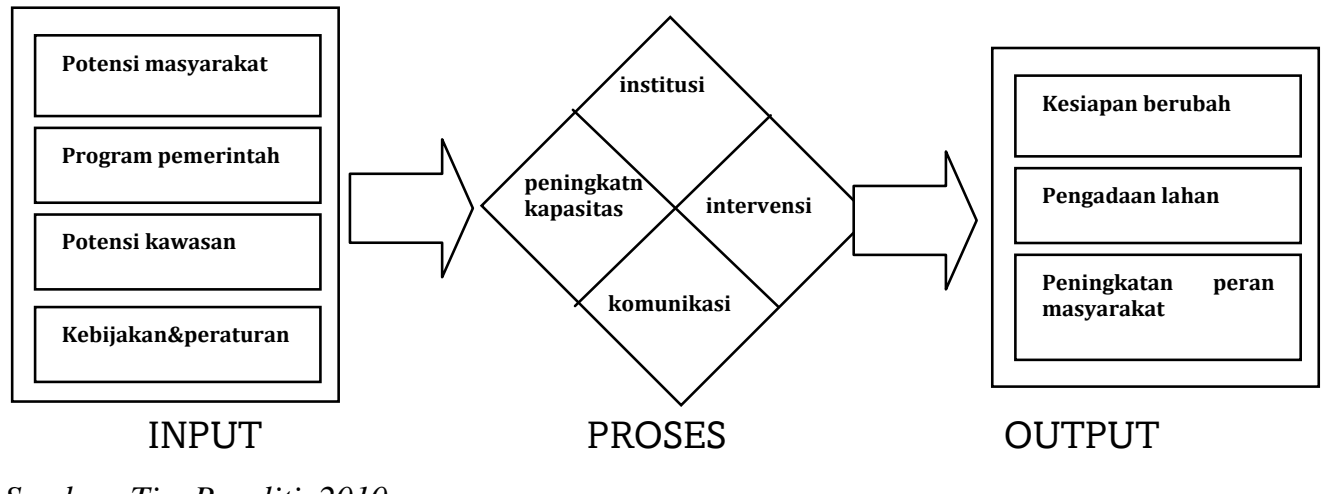

Sumber: Tim Peneliti, 2010

Gambar 5. Alur proses penguatan sosial

Kawasan Kumuh Perkotaan sebagaimana kawasan lainnya di perkotaan, harus dapat mengakomodasi prinsip sinergi kerja antara pemerintah, komunitas, profesional, dan pengguna layanan. Hal ini diperlukan untuk pengambilan keputusan, perancangan dan implementasi program bagi peningkatan aspek sosial dengan menggunakan sumber daya, komitmen dan keahlian yang ada. Penguatan sosial pada kawasan kumuh perkotaan dilakukan dengan mengumpulkan dan mengolah data untuk pelaksanaan kegiatan. Kegiatan diawali dengan membuat daftar kebutuhan data, dilanjutkan dengan melakukan pengumpulan data (misal dengan pemetaan swadaya), penggunaan data, dan pengembangan sistem informasi. 
Rancangan kegiatan seperti terlihat dalam gambar 6, menunjukan peran governansi, yaitu pengelolaan wewenang dalam mengatur kehidupan publik dari pihak pemerintah dan masyarakat, berperan penting dalam aspek sosial-ekonomi. Sebagai upaya mengantisipasi karakter dan profil psikodemografis daerah kumuh yang beragam, pola governansi dilakukan untuk menjamin peningkatan kualitas sosial. Masyarakat perlu dengan jelas melihat nilai tambah yang ditawarkan dan bagaimana nilai tambah ini sampai ke mereka. Kegiatan penataan kawasan kumuh harus dapat memastikan bagaimana nilai tambah ini diciptakan, terutama oleh aktivitas utama masyarakat bersama-sama mitra kerja.

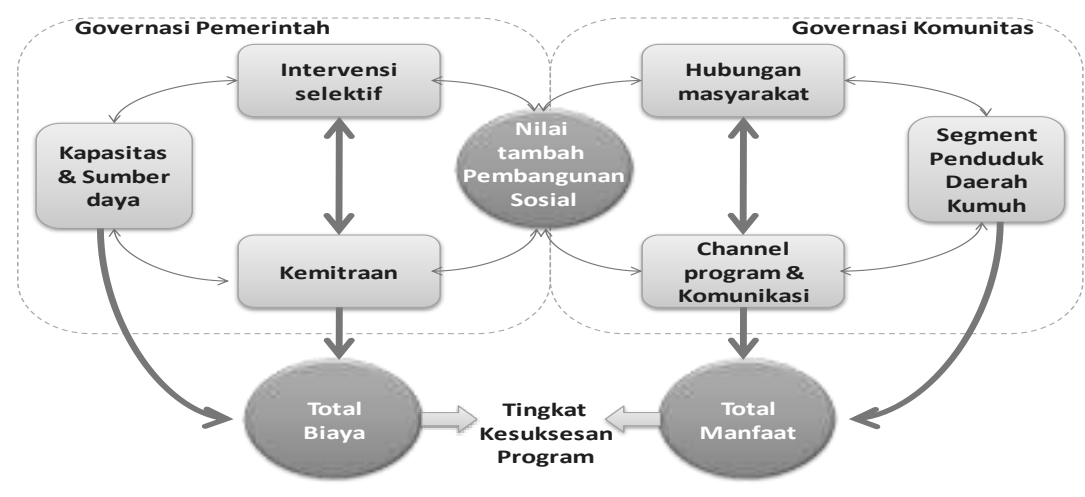

Sumber: Tim Peneliti, 2010

Gambar 6. Aktifitas Penguatan Sosial pada Penataan Kawasan Kumuh Perkotaan

\section{Kesimpulan}

Peningkatan kapasitas governansi pemerintah dapat dilakukan dengan mendorong Pimpinan Daerah, memberikan komitmen untuk menetapkan Kawasan Prioritas dalam peningkatan kualitas sosial wilayah. Membentuk unit kerja Pengelola Kawasan yang memiliki tugas meningkatkan kualitas sosial pada penataan kawasan kumuh.

Peningkatan kapasitas governansi komunitas masyarakat dapat dilakukan dengan pemberian komitmen warga, terlibat aktif dalam pengambilan keputusan, perencanaan, implementasi, pemeliharaan, pengawasan dan kontribusi peningkatan kualitas sosial ekonomi pada penataan kawasan kumuh prioritas.

Sinergitas kerja pemerintah dan masyarakat dapat diwujudkan dalam kerangka kemitraan, yaitu kerjasama operasional berbasis lokasi atau kerjasama berbasis sumber luar/ out source. Pembiayaan kegiatan dapat berbentuk uang tunai maupun natura lain, yang komposisinya mempertimbangkan efektifitas tujuan program.

\section{Daftar Pustaka}

Andini, Ike, 2013, Sikap dan Peran Pemerintah Kota Surabaya terhadap Perbaikan Daerah Kumuh di Kelurahan Tanah Kalikedinding Kota Surabaya, Kebijakan dan Manajemen Publik, Volume 1, Nomor 1, Januari 2013

Basri, Hasyim dan Ispurwono, dan Soemardiono, 2010, Model Penanganan Permukiman Kumuh, Studi Kasus Permukiman Kumuh Kelurahan Pontap Kecamatan Wara Timur Kota Palopo, Seminar Nasional Perumahan Permukiman dalam Pembangunan Kota 2010 
Suprijanto, Iwan, 2004, Reformasi Kebijakan \& Strategi Penyelenggaraan Perumahan \& Permukiman, Dimensi Teknik Arsitektur Vol. 32, No. 2, Desember 2004: 161 - 170, Jurusan Teknik Arsitektur, Fakultas Teknik Sipil dan Perencanaan - Universitas Kristen Petra.

Tim Peneliti, 2010, Peningkatan Kualitas Sosial dan Ekonomi Dalam Rangka Penataan Kawasan Kumuh Perkotaan, Balai Litbang Sosial Ekonomi Bidang Permukiman. Yogyakarta

Tim Peneliti, 2008, Laporan Penelitian Pengembangan Model Pendampingan Masyarakat dalam Peremajaan Kawasan Kumuh Perkotaan, Balai Litbang Sosial Ekonomi, Yogyakarta

Handayani, Sri, 2009, Penerapan Metode Penelitian Participatory Research Apraisal dalam Penelitian Permukiman Vernakular (Permukiman Kampung Kota), Proceeding Seminar Nasional Penelitian Arsitektur - Metoda dan Penerapannya Seri 2 UNDIP Semarang

Harry Hikmat, (2000), Andalsos : Pascasarjana Manajemen Pembangunan Sosial, Analisis Dampak Lingkungan Sosial : Strategi Menuju Pembangunan Berpusat Pada Rakyat (People Centred Development), UI, Jakarta

Hermanto, E, 2011, Permasalahan Lingkungan di Permukiman Kumuh Kota Medan (Studi Kasus di Kecamatan Medan Belawan), Semai Teknologi, Volume 5, Nomor 1, Juni 2011

Heston, Yudha, 2011, Peran Aspek Sosial Ekonomi dalam Penataan Kawasan Kumuh Perkotaan, Buletin Cipta Karya - 08/Tahun IX/Agustus 2011

Tanuwidjaja, Gunawan, Mustakim, Hidayat, Maman, Sudarman, Agus, 2009, Integrasi Kebijakan Perencanaan dan Desain Rumah Susun yang Berkelanjutan, dalam Konteks Pembangunan Kota yang Berkelanjutan In: Seminar Nasional 2009 oleh Univ.Kristen Maranatha, 15 Agustus 2009, Bandung.

Widigdo, Wanda dan Hartono, Samuel, Bantaran Kali Jagir, Surabaya sebagai Ruang Terbuka Hijau (RTH). http://fportfolio.petra.ac.id/ 